Pacific Journal of Mathematics

ON THE CONVERGENCE OF RATIONAL FUNCTIONS WHICH 


\title{
ON THE CONVERGENCE OF RATIONAL FUNCTIONS WHICH INTERPOLATE IN THE ROOTS OF UNITY
}

\author{
E. B. SAFF AND J. L. WALSH
}

\begin{abstract}
Results are obtained on the existence and convergence of certain types of rational functions which interpolate in the roots of unity to a function $f$ which is meromorphic in $|z|<1$ and continuous on $|z| \leqq 1$. The theorems presented extend results of Fejér and Walsh and Sharma on interpolating polynomials.
\end{abstract}

In a recent paper [2] the first author investigated the convergence of certain sequences of rational functions which interpolate to a meromorphic function $f$. The results obtained in [2] apply, for example, when $f$ is analytic on $|z| \leqq 1$, meromorphic in $|z|<\rho, \rho>1$, and the points of interpolation are the roots of unity.

In this paper we study the convergence of rational functions which interpolate in the roots of unity to a function $f$ which is meromorphic in $|z|<1$ and continuous on $|z| \leqq 1$. The theorems presented extend those of Fejér [1] and Walsh and Sharma [4] concerning interpolating polynomials. The method of proof of Theorem 1 is basically that of [2].

A rational function $r_{n \nu}(z)$ is said to be of type $(n, \nu)$ if it is of the form

$$
r_{n \nu}(z)=p_{n}(z) / q_{\nu}(z), \quad q_{\nu}(z) \not \equiv 0,
$$

where $p_{n}(z)$ and $q_{\nu}(z)$ are polynomials of degrees at most $n$ and $\nu$ respectively.

THEOREM 1. Let $f(z)$ be meromorphic with precisely $\nu$ poles (multiplicity included) in $D:|z|<1$ and otherwise finite and continuous on $|z| \leqq 1$. Let $D^{\prime}$ denote the domain obtained from $D$ by deleting the $\nu$ poles of $f(z)$. Then for all $n$ sufficiently large there exists a unique rational function $r_{n \nu}(z)$ of type $(n, \nu)$ which interpolates to $f(z)$ in the $n+\nu+1$ roots of unity. Each $r_{n \nu}(z)$ for $n$ large enough has precisely $\nu$ finite poles and as $n \rightarrow \infty$ these poles approach respectively the $\nu$ poles of $f(z)$ in $D$. The sequence $r_{n \nu}(z)$ converges to $f(z)$ throughout $D^{\prime}$, uniformly on any closed subset of $D^{\prime}$.

For the case $\nu=0$ the above theorem is due to Fejér [1].

Proof. For any function $g$ defined on $|z|=1$ the unique polynomial of degree at most $n$ which interpolates to $g$ in the $n+1$ roots 
of unity shall be denoted by $L_{n}(g ; z)$.

Let $\alpha_{1}, \alpha_{2}, \cdots, \alpha_{\nu}$ be the $\nu$ poles of $f(z)$ in $D$ and set

$$
\begin{gathered}
Q_{0}(z)=1, \quad Q_{k}(z)=\prod_{i=1}^{k}\left(z-\alpha_{i}\right), \quad 1 \leqq k \leqq \nu, \\
q_{n}(z)=Q_{\nu}(z)+\sum_{k=1}^{\nu} \alpha_{k}^{(n)} Q_{k-1}(z) .
\end{gathered}
$$

We shall show that for $n$ sufficiently large the coefficients $a_{k}^{(n)}$ can be chosen so that $Q_{\nu}(z)$ divides the interpolating polynomial $L_{n+\nu}\left(q_{n} Q_{\nu} f ; z\right)$. For simplicity we assume that the points $\alpha_{j}$ are distinct, i.e., $f(z)$ has only simple poles in $D$. The case of multiple poles is left to the reader.

Clearly $Q_{\nu}(z) \mid L_{n+\nu}\left(q_{n} Q_{\nu} f ; z\right)$ if and only if

$$
\sum_{k=1}^{\nu} c_{j k}^{(n)} a_{k}^{(n)}=d_{j}^{(n)}, \quad j=1,2, \cdots, \nu,
$$

where

$$
c_{j k}^{(n)}=L_{n+\nu}\left(Q_{k-1} Q_{\nu} f ; \alpha_{j}\right), \quad d_{j}^{(n)}=-L_{n+\nu}\left(Q_{\nu}^{2} f ; \alpha_{j}\right) .
$$

For each $k$ the function $Q_{k-1} Q_{\nu} f$ is analytic in $D$ and continuous on $|z| \leqq 1$, and so Fejér's theorem implies that

$$
\lim _{n \rightarrow \infty} c_{j k}^{(n)}=\left(Q_{k-1} Q_{\nu} f\right)\left(\alpha_{j}\right), \quad \lim _{n \rightarrow \infty} d_{j}^{(n)}=-\left(Q_{\nu}^{2} f\right)\left(\alpha_{j}\right), \quad 1 \leqq j, k \leqq \nu,
$$

Since $\alpha_{j}$ is a simple pole of $f$ we have

$$
\begin{array}{ll}
\left(Q_{k-1} Q_{\nu} f\right)\left(\alpha_{j}\right)=0, & \text { for } k>j, \\
\left(Q_{k-1} Q_{\nu} f\right)\left(\alpha_{j}\right) \neq 0, & \text { for } k=j .
\end{array}
$$

Hence

$$
\lim _{n \rightarrow \infty} \operatorname{det}\left[c_{j k}^{(n)}\right]=\prod_{l=1}^{\nu}\left(Q_{l-1} Q_{\nu} f\right)\left(\alpha_{l}\right) \neq 0,
$$

which implies that for $n$ sufficiently large the linear system (1) can be solved uniquely for the coefficients $a_{j}^{(n)}$. Furthermore since $d_{j}^{(n)} \rightarrow 0$ as $n \rightarrow \infty$, it follows from Cramer's rule that for each $k, 1 \leqq k \leqq \nu$, we have $a_{k}^{(n)} \rightarrow 0$ as $n \rightarrow \infty$. Thus

$$
\lim _{n \rightarrow \infty} q_{n}(z)=Q_{\nu}(z),
$$

uniformly on each bounded subset of the plane.

Now set $r_{n \nu}(z) \equiv L_{n+\nu}\left(q_{n} Q_{\nu} f ; z\right) / q_{n}(z) Q_{\nu}(z)$. Then by our choice of the coefficients $a_{k}^{(n)}$ we have that $r_{n \nu}(z)$ is a rational function of type $(n, \nu)$. Also from (2) it follows that for $n$ sufficiently large $q_{n}(z)$ is different from zero in the $n+\nu+1$ roots of unity and so $r_{n \nu}(z)$ must 
interpolate to $f(z)$ in these points. It is easy to see that $r_{n \nu}(z)$ is uniquely determined by its interpolation property. From Fejér's theorem and (2) we have $r_{n \nu}(z) \rightarrow f(z)$ as $n \rightarrow \infty$ uniformly on any closed subset of $D^{\prime}$.

Finally note that $r_{n \nu}(z)$ has $\nu$ formal poles, namely the zeros of $q_{n}(z)$, and as $n \rightarrow \infty$ these poles approach respectively the $\nu$ poles of $f(z)$ in $D$. Since

$$
\lim _{n \rightarrow \infty} L_{n+\nu}\left(q_{n} Q_{\nu} f ; z\right) / Q_{\nu}(z)=Q_{\nu}(z) f(z),
$$

uniformly for $z$ in a neighborhood of each $\alpha_{j}$, it follows that for $n$ sufficiently large no zero of the polynomial $L_{n+\nu}\left(q_{n} Q_{\nu} f ; z\right) / Q_{\nu}(z)$ is a zero of $q_{n}(z)$. Thus the $\nu$ formal poles of $r_{n \nu}(z)$ are actual poles. This completes the proof of Theorem 1 .

Walsh and Sharma [4] have shown that for any function $g(z)$ analytic in $|z|<1$ and continuous on $|z| \leqq 1$, the sequence $L_{n}(g ; z)$ converges to $g(z)$ on $|z|=1$ in the mean of second order. Applying this result to each of the sequences $\left\{L_{n+\nu}\left(Q_{k-1} Q_{\nu} f ; z\right)\right\}, 1 \leqq k \leqq \nu+1$, there follows from (2)

THEOREM 2. The sequence $r_{n \nu}(z)$ of Theorem 1 converges to $f(z)$ in the mean of second order on $|\boldsymbol{z}|=1$.

Theorems 1 and 2 are another illustration of the close analogy between approximation in the sense of least squares on $|z|=1$ and interpolation in the roots of unity; compare [3, $\$ \S 7.10,9.1,11.6]$, [4].

\section{REFERENCES}

1. L. Fejér, Interpolation und konforme Abbildung, Göttinger Nachrichten, (1918), 319-331.

2. E. B. Saff, An extension of Montessus de Ballore's theorem on the convergence of interpolating rational functions, J. Approximation Theory, vol. 6 (1972), 63-67.

3. J. L. Walsh, Interpolation and Approximation, vol. 20 of Coll. Pubs., Amer. Math. Soc., Providence, R. I., 1969.

4. J. L. Walsh and A. Sharma, Least squares and interpolation in roots of unity, Pacific J. Math., 14 (1964), 727-730.

November 10, 1971. The research of the authors was supported, in part, by NSF Grant GF-19275 and USAF Grant 69-1690 respectively.

UNIVERSITY OF SOUTH FLORIDA

AND

UNIVERSITY OF MARYLAND 



\section{PACIFIC JOURNAL OF MATHEMATICS}

\section{EDITORS}

\author{
H. SAMELson \\ Stanford University \\ Stanford, California 94305 \\ C. R. HоввY \\ University of Washington \\ Seattle, Washington 98105
}

J. DugundJI

Department of Mathematics

University of Southern California

Los Angeles, California 90007

RICHARD ARENS

University of California

Los Angeles, California 90024

\section{ASSOCIATE EDITORS}
E. F. BeCKENBACH
B. H. NEUMANN
F. WOLF
K. YoshidA

\section{SUPPORTING INSTITUTIONS}

UNIVERSITY OF BRITISH COLUMBIA

CALIFORNIA INSTITUTE OF TECHNOLOGY

UNIVERSITY OF CALIFORNIA

MONTANA STATE UNIVERSITY

UNIVERSITY OF NEVADA

NEW MEXICO STATE UNIVERSITY

OREGON STATE UNIVERSITY

UNIVERSITY OF OREGON

OSAKA UNIVERSITY

\author{
UNIVERSITY OF SOUTHERN CALIFORNIA \\ STANFORD UNIVERSITY \\ UNIVERSITY OF TOKYO \\ UNIVERSITY OF UTAH \\ WASHINGTON STATE UNIVERSITY \\ UNIVERSITY OF WASHINGTON

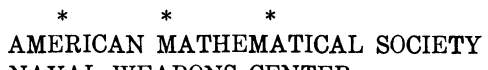 \\ NAVAL WEAPONS CENTER
}

The Supporting Institutions listed above contribute to the cost of publication of this Journal, but they are not owners or publishers and have no responsibility for its content or policies.

Mathematical papers intended for publication in the Pacific Journal of Mathematics should be in typed form or offset-reproduced, (not dittoed), double spaced with large margins. Underline Greek letters in red, German in green, and script in blue. The first paragraph or two must be capable of being used separately as a synopsis of the entire paper. The editorial "we" must not be used in the synopsis, and items of the bibliography should not be cited there unless absolutely necessary, in which case they must be identified by author and Journal, rather than by item number. Manuscripts, in duplicate if possible, may be sent to any one of the four editors. Please classify according to the scheme of Math. Rev. Index to Vol. 39. All other communications to the editors should be addressed to the managing editor, Richard Arens, University of California, Los Angeles, California, 90024.

50 reprints are provided free for each article; additional copies may be obtained at cost in multiples of 50 .

The Pacific Journal of Mathematics is issued monthly as of January 1966. Regular subscription rate: $\$ 48.00$ a year (6 Vols., 12 issues). Special rate: $\$ 24.00$ a year to individual members of supporting institutions.

Subscriptions, orders for back numbers, and changes of address should be sent to Pacific Journal of Mathematics, 103 Highland Boulevard, Berkeley, California, 94708.

PUBLISHED BY PACIFIC JOURNAL OF MATHEMATICS, A NON-PROFIT CORPORATION

Printed at Kokusai Bunken Insatsusha (International Academic Printing Co., Ltd.), 270, 3-chome Totsuka-cho, Shinjuku-ku, Tokyo 160, Japan. 


\section{Pacific Journal of Mathematics}

\section{Vol. 45, No. $2 \quad$ October, 1973}

Kenneth Paul Baclawski and Kenneth Kapp, Induced topologies for quasigroups and loops ............................................. 393

D. G. Bourgin, Fixed point and $\min -\max$ theorems $\ldots \ldots \ldots \ldots \ldots \ldots \ldots$

J. L. Brenner, Zolotarev's theorem on the Legendre symbol ............... 413

Jospeh Atkins Childress, Jr., Restricting isotopies of spheres .............. 415

John Edward Coury, Some results on lacunary Walsh series ................ 419

James B. Derr and N. P. Mukherjee, Generalized Sylow tower groups. II . . . . . . 427

Paul Frazier Duvall, Jr., Peter Fletcher and Robert Allen McCoy, Isotopy Galois

spaces .......................................... 435

Mary Rodriguez Embry, Strictly cyclic operator algebras on a Banach space ... 443

Abi (Abiadbollah) Fattahi, On generalizations of Sylow tower groups ......... 453

Burton I. Fein and Murray M. Schacher, Maximal subfields of tensor products . . 479

Ervin Fried and J. Sichler, Homomorphisms of commutative rings with unit

element .......................................... 485

Kenneth R. Goodearl, Essential products of nonsingular rings ............. 493

George Grätzer, Bjarni Jónsson and H. Lakser, The amalgamation property in

equational classes of modular lattices ...........................

507

$\mathrm{H}$. Groemer, On some mean values associated with a randomly selected simplex

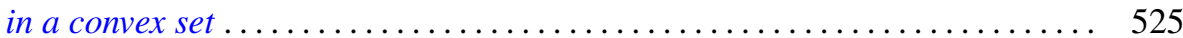

Marcel Herzog, Central 2-Sylow intersections .................... 535

Joel Saul Hillel, On the number of type-k translation-invariant groups ........ 539

Ronald Brian Kirk, A note on the Mackey topology for $\left(C^{b}(X)^{*}, C^{b}(X)\right) \ldots \ldots .543$

J. W. Lea, The peripherality of irreducible elements of lattice.............. 555

John Stewart Locker, Self-adjointness for multi-point differential operators ..... 561

Robert Patrick Martineau, Splitting of group representations ............... 571

Robert Massagli, On a new radical in a topological ring ................. 577

James Murdoch McPherson, Wild arcs in three-space. I. Families of Fox-Artin

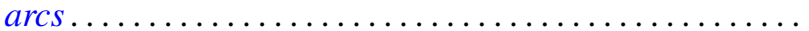

585

James Murdoch McPherson, Wild arcs in three-space. III. An invariant of

oriented local type for exceptional arcs . . . . . . . . . . . . ............ 599

Fred Richman, The constructive theory of countable abelian p-groups ........ 621

Edward Barry Saff and J. L. Walsh, On the convergence of rational functions

which interpolate in the roots of unity ..................

Harold Eugene Schlais, Non-aposyndesis and non-hereditary

decomposability..................................... 643

Mark Lawrence Teply, A class of divisible modules................... 653

Edward Joseph Tully, Jr., H-commutative semigroups in which each

homomorphism is uniquely determined by its kernel ................. 669

Garth William Warner, Jr., Zeta functions on the real general linear group ...... 681

Keith Yale, Cocyles with range $\{ \pm 1\} \ldots \ldots \ldots \ldots \ldots \ldots \ldots \ldots \ldots \ldots \ldots \ldots \ldots . \ldots \ldots$

Chi-Lin Yen, On the rest points of a nonlinear nonexpansive semigroup ........ 699 